\title{
Effect of bioaugmentation on long-term biodegradation of diesel/biodiesel blends in soil microcosms
}

Woniak-Karczewska, Marta; Lisiecki, Piotr; Biaas, Wojciech; Owsianiak, Mikoaj; Piotrowska-Cyplik, Agnieszka; Wolko, ukasz; awniczak, ukasz; Heipieper, Hermann J.; Gutierrez, Tony; Chrzanowski, ukasz

Published in:

Science of the Total Environment

Link to article, DOI:

10.1016/j.scitotenv.2019.03.431

Publication date:

2019

Document Version

Peer reviewed version

Link back to DTU Orbit

Citation (APA):

Woniak-Karczewska, M., Lisiecki, P., Biaas, W., Owsianiak, M., Piotrowska-Cyplik, A., Wolko, ., awniczak, Heipieper, H. J., Gutierrez, T., \& Chrzanowski, . (2019). Effect of bioaugmentation on long-term biodegradation of diesel/biodiesel blends in soil microcosms. Science of the Total Environment, 671, 948-958. https://doi.org/10.1016/j.scitotenv.2019.03.431

\section{General rights}

Copyright and moral rights for the publications made accessible in the public portal are retained by the authors and/or other copyright owners and it is a condition of accessing publications that users recognise and abide by the legal requirements associated with these rights.

- Users may download and print one copy of any publication from the public portal for the purpose of private study or research.

- You may not further distribute the material or use it for any profit-making activity or commercial gain

- You may freely distribute the URL identifying the publication in the public portal 


\section{Accepted Manuscript}

Effect of bioaugmentation on long-term biodegradation of diesel/ biodiesel blends in soil microcosms

Marta Woźniak-Karczewska, Piotr Lisiecki, Wojciech Białas, Mikołaj Owsianiak, Agnieszka Piotrowska-Cyplik, Łukasz Wolko, Łukasz Ławniczak, Hermann J. Heipieper, Tony Gutierrez, Łukasz Chrzanowski

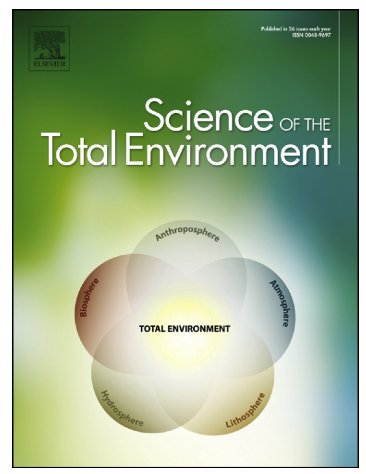

PII:

S0048-9697(19)31442-1

DOI:

https://doi.org/10.1016/j.scitotenv.2019.03.431

Reference:

STOTEN 31641

To appear in:

Science of the Total Environment

Received date:

17 December 2018

Revised date:

26 March 2019

Accepted date:

27 March 2019

Please cite this article as: M. Woźniak-Karczewska, P. Lisiecki, W. Białas, et al., Effect of bioaugmentation on long-term biodegradation of diesel/biodiesel blends in soil microcosms, Science of the Total Environment, https:/doi.org/10.1016/ j.scitotenv.2019.03.431

This is a PDF file of an unedited manuscript that has been accepted for publication. As a service to our customers we are providing this early version of the manuscript. The manuscript will undergo copyediting, typesetting, and review of the resulting proof before it is published in its final form. Please note that during the production process errors may be discovered which could affect the content, and all legal disclaimers that apply to the journal pertain. 
Effect of bioaugmentation on long-term biodegradation of diesel/biodiesel blends in soil microcosms

Marta Woźniak-Karczewska ${ }^{\mathrm{a}}$

Piotr Lisiecki ${ }^{\mathrm{a}}$

Wojciech Białas ${ }^{\mathrm{b}}$

Mikołaj Owsianiak $^{\mathrm{c}}$

Agnieszka Piotrowska-Cyplik ${ }^{\mathrm{d}}$

Lukasz Wolko

Łukasz Ławniczak $^{\mathrm{a}}$

Hermann J. Heipieper ${ }^{\mathrm{f}}$

Tony Gutierrez ${ }^{\mathrm{g}}$

Łukasz Chrzanowski*a

${ }^{a}$ Institute of Chemical Technology and Engineering, Poznan University of Technology, Pl.

M. Skłodowskiej-Curie 2, 60-965 Poznań, Poland

${ }^{\mathrm{b}}$ Department of Biotechnology and Food Microbiology, Poznan University of Life Sciences, Wojska Polskiego 48, 60-627 Poznań, Poland

c Division for Quantitative Sustainability Assessment, Department of Management Engineering, Technical University of Denmark, Bygningstorvet, Building 116B, DK-2800 Kgs. Lyngby, Denmark

${ }^{\mathrm{d}}$ Institute of Food Technology of Plant Origin, Poznan University of Life Sciences, Wojska Polskiego 31, 60-624, Poznan, Poland,

${ }^{\mathrm{e}}$ Department of Biochemistry and Biotechnology, Poznan University of Life Sciences, Dojazd 11, 60-632, Poznan, Poland 
${ }^{\mathrm{f}}$ Helmholtz Centre for Environmental Research - UFZ, Department of Environmental Biotechnology, Permoserstraße 15, D-04318 Leipzig, Germany

${ }^{\mathrm{g}}$ Institute of Mechanical, Process and Energy Engineering (IMPEE), School of Engineering and Physical Sciences, Heriot-Watt University, EH14 4AS Edinburgh, UK

* corresponding author

Łukasz Chrzanowski

Tel.: + 48616653716

Fax.: + 48616653649

E-mail: lukasz.chrzanowski@put.poznan.pl 


\begin{abstract}
We studied long-term (64.5 weeks) biodegradation of diesel fuel, diesel/biodiesel blends (B10-B90) and biodiesel fuels in urban soil microcosms containing indigenous microorganisms, or indigenous microorganisms augmented with a hydrocarbon-degrading bacterial community. Mineralization extent ( $\mathrm{mmol}$ of $\mathrm{CO}_{2}$ per day) of B10-B30 blends was smaller compared with diesel fuel at both short- (28 days) and long-term (109 days), and increased with biodiesel content. Priming with hydrocarbon degraders accelerated mineralization in the short-term (by up to $140 \%$ ), with highest influence using blends with lower biodiesel content, but did not significantly influence kinetics and mineralization extent in the long-term. Although the biodiesel fraction was degraded completely within 64.5 weeks, $3-12 \%$ of the total aromatic and aliphatic hydrocarbons remained in the microcosms. Barcoded 16S rRNA gene MiSeq sequencing analysis revealed a significant effect of blend type on the community structure, with a marked enrichment of Sphingobacteriia and Actinobacteria classes. However, no significant influence was determined in the long-term, suggesting that the inoculated bacterial community may not have survived. Our findings show that biodiesel is preferentially degraded in urban soil and suggest that the value of bioaugmentation for bioremediating biodiesel fuels with hydrocarbon-degrading bacteria is limited to short-term exposures to lower (B10-B30) blends.
\end{abstract}

\title{
Keywords
}

Bacterial community, fuel blends, hydrocarbons, mineralization, MiSeq sequencing 


\section{Introduction}

Petroleum diesel fuel is often blended with biodiesel [fatty acid methyl esters (FAMEs)] before being introduced to the market (Luque et al., 2010). Biodiesel mixed with petroleum diesel fuel can be used in unmodified diesel engines in different proportions ranging from $2 \%$ to $20 \%$ depending on government policy (DeMello et al., 2007; Luque et al., 2010). In Germany, the pure biodiesel is available and used in transportation without being taxed (Demirbas, 2017). However, in the rest of the European Union, the addition of biodiesel to conventional fuel is approximately 5\% (Bücker et al., 2011; Schleicher et al., 2009). This blending generally has a positive influence on biodegradation rates of fuel (Horel and Schiewer, 2011; Silva et al., 2012). Several studies have focused on the effect of biodiesel in accelerating the biodegradation in sediments and soils (Miller and Mudge, 1997; Taylor and Jones, 2001). Miller and Mudge (1997) reported the addition of biodiesel to enhance biodegradation of petroleum hydrocarbons in sediments contaminated with crude oil. This phenomenon is generally explained by the fact that the FAMEs are preferentially utilized by microorganisms over the petroleum hydrocarbons. For example, Horel and Schiewer (2011) measured that biodiesel stimulated microbial populations in sandy soil, thereby increasing biodegradation rates of the blends. This effect is usually explained by the structural similarities between FAMEs and $n$-alkanes, as well as similarities in their metabolic mechanisms (Yassine et al., 2013). DeMello et al. (2007) reported the degradation rate constants for FAMEs and $n$-alkanes in seawater were comparable. This corroborates with the study by Yassine et al. (2013) which described higher $n$-alkane degradation rates in biodiesel blends with acclimated microbial cultures as attributed to the ability of FAMEs to be cosolubilized with $n$-alkanes. Moreover, these studies emphasized that biodegradation of aromatic compounds was also affected by biodiesel blending. A key factor when considering the influence of biodiesel on biodegradation of diesel in soil is the ability of the former to act 
as solubilizing agent (Fernández-Álvarez et al., 2007; Miller and Mudge, 1997). According to Fernández-Álvarez et al. (2007), among the different bioremediation agents (microorganisms, nutrients and biodiesel) that can be used, only biodiesel has been shown to accelerate the biodegradation of both aliphatic and aromatic fractions of heavy fuel oil. On the other hand, Mariano et al. (2008) observed no effect of biodiesel on diesel biodegradation in soil and water in an experiment lasting over 120 days. Leme et al. (2012) showed the mutagenic and genotoxic effects of biodiesel and its diesel blends in soil matrix, emphasizing the potential harmful effects of biodiesel. However, there remains a paucity of knowledge regarding the long-term influence of biodiesel on the biodegradation of different hydrocarbon fractions in diesel/biodiesel blends in complex soil matrix.

The use of isolated microbial communities, consortia or specific populations of microorganisms (El Fantroussi and Agathos, 2005) for the in situ treatment of polluted sites also called bioaugmentation - has been considered a useful approach to increase bioremediation efficiency (Atashgahi et al., 2018; Di Gregorio et al., 2016; Lladó et al., 2012; Meyer et al., 2014). Positive results were described by Teng et al. (2010), who showed that addition of hydrocarbon-degrading strains enhanced the bioremediation of soil contaminated with polycyclic aromatic hydrocarbons (PAHs), while Szczepaniak et al. (2016) showed the effectiveness of using PAH-degrading consortia during the early stage of bioaugmentation treatment. Both studies highlighted the stimulatory effect of autochthonous microorganisms with the addition of exogenous hydrocarbon-degrading microorganisms over the short-term. However, there are also contradictory studies that reported either a negative or no effect by bioaugmentation (Bouchez et al., 2000; Saponaro et al., 2001; Silva et al., 2009). No significant effect on biodegradation of PAHs after fungal and bacterial consortia introduction into soil were observed by Silva et al. (2009). The study by Bouchez et al. (2000) indicated the difficulties in adaptation of augmented microorganisms to a well-adapted initial bacterial 
population. According to El Fantroussi and Agathos (2005), bioaugmentation is still in the experimental phase with no general guidelines for how to efficiently introduce external microorganisms to treat a contaminated site. Recently, however, Horemans et al. (2016) presented a three-step approach emphasizing the importance of compatibility of microorganisms and soil selection to the success of bioaugmentation treatments. This was also mentioned by Bento et al. (2005), who showed that an effective bioaugmentation approach for treatment of diesel oil contaminated sites can depend on soil properties as well as indigenous soil microorganisms. Bioaugmentation treatments with bacteria (Meyer et al., 2014, 2012) and fungi (Junior et al., 2009) have been successfully applied for diesel/biodiesel blends, where the biodegradation of different blends were higher compared with non-bioaugmented set-ups. However, many studies concern the biodegradation of only a limited range of blends, such as B2, B5, B20 or B50 (Bücker et al., 2011; Meyer et al., 2014; Schleicher et al., 2009) or the experiments were conducted over short periods of 28, 60 or 84 days (Horel and Schiewer, 2011; Schleicher et al., 2009; Silva et al., 2012). Therefore, it is difficult to generalize about the effectiveness of bioaugmentation on degradation of wide range of diesel/biodiesel blends during long-term exposure, as well as due to the variability in soil types, their autochthonous microbial communities, and the experimental approaches performed across different laboratories.

Here, we examined the effects of biodiesel on the biodegradation of aliphatic and aromatic fractions in a wide range of diesel/biodiesel blends. Long-term biodegradation experiments were conducted in urban soil microcosms in two parallel variants: autochthonic microcosms versus autochthonic microcosms bioaugmented with a hydrocarbon-degrading community that was previously isolated from contaminated soil. The response of the autochthonic microbial community towards increasing biodiesel concentration, and that of the 
exogenously-added hydrocarbon-degrading community, was analyzed by $16 \mathrm{~S}$ rRNA gene sequencing using Illumina MiSeq technology.

\section{Materials and Methods}

\subsection{Fuels}

Diesel fuel (EN 590:2004), assigned as D was purchased from a petrol station (PKN Orlen, Poland). Biodiesel (assigned as B100) was produced from rapeseed oil (DIN V 51606) and obtained from PetroTec AG in Germany. In addition to these two types of fuels, nine diesel/biodiesel blends with increasing by $10 \%$ biodiesel content that is from 10 to $90 \%(\mathrm{v} / \mathrm{v}$ ) (assigned B10, B20, B30, B40, B50, B50, B60 B70, B80, and B90) were prepared by batching in laboratory and mixing volumetric portions of diesel and biodiesel fuels. Two methyl ester of oleic acid (C18:1) and linoleic acid (C18:2) constituted a majority of $68 \%$ and $21 \%$ of the biodiesel respectively, while the remaining $11 \%$ consisted of methyl esters of C16:0, C18:0, C20:0 and C20:1 (Lisiecki et al., 2014).

\subsection{Microorganisms}

The bacterial community that was used in this study - designated BC125 - was isolated from crude oil-contaminated soil (Gorlice, Małopolska, Poland). The selectively enriched community was maintained using only mineral medium with diesel fuel as a sole carbon and energy source. Metagenomic analysis of V4 hypervariable region of the 16S rRNA gene identified 22 classes. The most dominant microbial classes detected in BC125 were Alphaproteobacteria (47.85\%), followed by Bacilli (22.71\%), Gammaproteobacteria (13.31\%), Actinobacteria (8.58\%), Clostridia (3.37\%), Betaproteobacteria (2.08\%) and Flavobacteriia (1.36\%). The community was tested with respect to structural and functional robustness when exposed to different hydrocarbons according to the report provided by 
Sydow et al. (2016). It was proved to maintain both structural and functional integrity when exposed to various aliphatic, cyclic and aromatic hydrocarbons. The bacterial community was able to efficiently degrade hydrocarbons in a pH range of 6.5-7.5.

The BC125 was stored as glycerol stocks $(20 \% \mathrm{v} / \mathrm{v})$ at $-80^{\circ} \mathrm{C}$ until used. A $1 \mathrm{ml}$ of stock suspension was transferred to Erlenmeyer flask (300 mL, SIMAX, Sazava, Czech Republic) with $50 \mathrm{~mL}$ of mineral medium supplemented with $0.5 \%(\mathrm{v} / \mathrm{v})$ diesel fuel as described in Sydow et al. (2016). The culture was incubated with shaking (120 rpm; $25^{\circ} \mathrm{C}$, Multitron; Infors HT, Bottmingen, Switzerland) for $24 \mathrm{~h}$. Subsequently, the cell suspension (1 mL) was transferred into fresh mineral medium $(50 \mathrm{~mL})$ and cultivated for $72 \mathrm{~h}$ in conditions described above. The final enrichment culture was obtained after three transfers. The fresh pre-culture $(50 \mathrm{~mL})$ for mineralization experiments were washed three times in sterile $\mathrm{NaCl}(0.85 \% \mathrm{v} / \mathrm{v})$ and subsequently incubated on mineral medium $(500 \mathrm{~mL})$ with $0.5 \%(\mathrm{v} / \mathrm{v})$ diesel fuel as described in Sydow et al. (2016). The BC125 was incubated (120 rpm; $\left.25^{\circ} \mathrm{C}\right)$ for to $48 \mathrm{~h}$. When optical density $\left(\mathrm{OD}_{600}\right)$ of the pre-culture reached approximately $3.0 \pm 0.1$, the cell suspension was centrifuged $\left(10,000 \mathrm{~g} ; 4^{\circ} \mathrm{C} ; 15 \mathrm{~min}\right.$, Heraeus Multifuge 3S-R, Hanau, Germany) and washed three times with mineral medium. The resuspended cells in medium served as inoculum for subsequent experiments.

\subsection{Characterization of soil}

Mollic gley soil used in this study was collected from a city park in Poznan, Poland (N 52.4011445, E 16.9222993) and previously characterized in Sydow et al. (2015). Briefly, the soil samples were taken from the depth of $10-20 \mathrm{~cm}$ and sieved $(2.0 \mathrm{~mm})$. The soil was characterized as fine-grained silt loam type OL (United Soil Classification System). The detailed composition of soil was as follows: clay, $4 \pm 1$ [\%]; silt, $83 \pm 3[\%]$; sand, $13 \pm 2[\%]$. The characteristics of the soil were as follows: organic carbon $5.44 \pm 0.31\left[\mathrm{~g} \mathrm{~kg}^{-1}\right]$; nitrogen 
$0.57 \pm 0.07\left[\mathrm{~g} \mathrm{~kg}^{-1}\right] ;$ phosphorous $0.080 \pm 0.005\left[\mathrm{~g} \mathrm{~kg}^{-1}\right] ; \mathrm{pH} 6.95 \pm 0.7$; bulk density $1.41 \pm$ $0.06\left[\mathrm{Mg} / \mathrm{m}^{3}\right]$; porosity $0.455 \pm 0.03\left[\mathrm{~m}^{3} / \mathrm{m}^{3}\right]$; moisture during sampling $18 \pm 1[\%]$; cation exchange capacity $22.1 \pm 0.8$ [cmolc $\left.\mathrm{kg}^{-1}\right]$. A symbol \pm represents standard deviation from three independent replicates.

\subsection{Microcosms and mineralization measurements}

To evaluate the mineralization extent of diesel (D) and biodiesel blends (B10-B100), $50 \mathrm{~g}$ of soil was placed in sterile pre-weighed $1000 \mathrm{~mL}$ SIMAX bottles (SIMAX, Sazava, Czech Republic). Subsequently, fuels $(0.75 \mathrm{~mL}$ of D or B10-B100) were spiked on the soil surface. The bottles were weighed again to determine the exact amount of fuels added to each bottle, which was essential for further analytical protocols ( $0.1 \mathrm{mg}$ accuracy). Average concentration of D and B10-B100 fuel was $12 \mathrm{~g} / \mathrm{kg}$ soil (approx. $1 \% \mathrm{v} / \mathrm{w}$, a level at which biological treatment is typically feasible). Each experimental setup was performed in triplicates, thus overall 33 samples with diesel/biodiesel blends were prepared. Another 33 samples with microcosms (50 g of soil) were first spiked with diesel/biodiesel blends as described above and then augmented with $\mathrm{BC} 125$ suspension ( $1 \mathrm{~mL}$; with final concentration $2 \times 10^{8} \mathrm{CFU} \mathrm{g}{ }^{-1}$ ) - further assigned as D+, B10+, B20+ etc. The non-augmented samples were amended with 1 $\mathrm{mL}$ of sterile mineral medium to maintain the soil field capacity at $85 \% \mathrm{v} / \mathrm{v}$ in all microcosms (augmented and non-augmented samples). Additionally, three biotic, non-spiked soil controls, three non-spiked, augmented with active BC125 soil controls and three non-spiked, augmented with killed inoculum (autoclaved immediately before inoculation) controls were also prepared. All samples were gently mixed and finally, all microcosms were incubated at $20^{\circ} \mathrm{C}$ for 64.5 weeks.

The mineralization extent of fuels was assessed by measurements of $\mathrm{CO}_{2}$ trapped in the base trap (10 $\mathrm{mL}$ of $0.75 \mathrm{M} \mathrm{NaOH}$ in a $20-\mathrm{mL}$ vial), and placed in each microcosm as described in 
Szulc et al. (2014). Titration with $0.1 \mathrm{M} \mathrm{HCl}$ of diluted $\mathrm{NaOH}$ and $\mathrm{Na}_{2} \mathrm{CO}_{3}$ solution from the trap, according to Warder method, was carried out with the use of automatic titrator (Metrohm titroprocessor 686, Herisau, Switzerland). After each measurement the content of the base trap was replaced with fresh $\mathrm{NaOH}$ solution. The samples were measured in different time intervals: every 1-3 days (I month), once to twice a week (II-III month), every two weeks (IVV month), once a month (VI-XII month), and the last measurements were performed 102 days after the penultimate measurement was taken (day 452).

\subsection{Hydrocarbon and FAME analyses}

After 64.5 weeks, the microcosms (three replicates for each setup) were sacrificed and the residual hydrocarbons and FAME were determined. Briefly, after removal of base traps, 12.5 $\mathrm{mL}$ of acetone was added into each bottle and the samples were vortexed for $1 \mathrm{~min}$ (VortexGenie 2 Shake, Scientific Industries, New York, US). Subsequently, $5 \mathrm{~g}$ of anhydrous $\mathrm{MgSO}_{4}$ was added and the samples were vortexed again. Next, $7.5 \mathrm{~mL}$ portion of $n$-hexane was added and vortexed for another $1 \mathrm{~min}$. The bottles were sonicated for $20 \mathrm{~min}$ in order to promote desorption of the analytes from solid matrix. The samples were shaken vigorously (Multitron; Infors HT, Bottmingen, Switzerland) after the first 10 min to homogenize soil sticking on the bottom of the flask. The samples were then shaken on a horizontal shaker ( $250 \mathrm{rpm} ; 15 \mathrm{~min}$ ). Subsequently, the obtained extract $(1 \mathrm{~mL})$ was washed with $0.1 \mathrm{M} \mathrm{NaOH}(3 \mathrm{~mL})$ to remove acetone and co-extracted acidic interferences and the upper phase further processed. One fraction of the extract was taken and cleaned on a Florisil column (Sigma Aldrich, St. Louis, US) for total hydrocarbon and FAME analysis; another fraction was also taken, but this time cleaned and fractionated on a Ag-impregnated silca gel column (Merck, Darmstadt, Germany) into saturated (aliphatic) and non-saturated (aromatic and FAME) fraction as described by Lisiecki et al. (2014). The resultant hydrocarbon fractions (aliphatic and aromatic) were 
finally determined with gas chromatography (GC-FID and GC×GC-TOF-MS, Agilent, Palo Alto, US) according to the procedures described elsewhere (Lisiecki et al., 2014). The results were presented as a ratio of remaining to initial masses of each fraction (total diesel/biodiesel blends, total hydrocarbons, aliphatic hydrocarbons, aromatic hydrocarbons and FAME). The presented error bars for the GC analysis results represent confidence intervals for $\mathrm{p}=0.05$.

\subsection{Evaluation of bacterial community structure in the soil}

The influence on qualitative and quantitative composition of microbial community samples was assessed using Illumina MiSeq sequencing (Illumina, San Diego, US). Here, Illumina genetic analysis was applied in order to investigate the potential changes in the bacterial community structure due to biodiesel content as well as bioaugmentation treatment. The contribution of most abundant microbial phyla and classes were presented as \% of total taxonomic rank.

Two additional samples of each treatment were setup for Illumina MiSeq sequencing, as described in section 2.4 above. After termination of the soil experiments, approximately $20 \mathrm{~g}$ of soil from central area of each experimental microcosm (ten random samples from depth of approx. $10 \mathrm{~cm}$ ) were collected and homogenized. The subsamples were divided into three equal portions and then stored at $-80{ }^{\circ} \mathrm{C}$ until used (no more than two weeks). Extraction of DNA and PCR amplification using universal primers were performed according to the procedure provided by Ławniczak et al. (2016) and Szczepaniak et al. (2016). Briefly, the isolation of the genetic material from analyzed samples was performed using appropriate Genomic Mini AX kits (A\&A Biotechnology, Gdynia, Poland), as recommended by the manufacturer. The validation of isolation efficiency was conducted with a fluorometric method by means of a Qubit ${ }^{\mathrm{TM}}$ dsDNA HS Assay Kit and Qbit 2.0 apparatus (ThermoFisher Scientific, Waltham, US). For PCR amplification and sequencing the universal prokaryote 
primers 515F-806R were applied to amplify the V4 region of the 16S rRNA gene (Caporaso et al., 2012). The PCR reaction $(25 \mu \mathrm{l})$ contained the following: $5 \mu \mathrm{l}$ microbial template genomic DNA, $5 \mu 1$ of each primer, $2.5 \mu 1$ of PCR-grade water (ThermoFisher Scientific, Waltham, US) and $12.5 \mu \mathrm{l}$ of PCR Master Mix with the Taq polymerase (ThermoFisher Scientific, Waltham, US). The thermocycler (ThermoFisher Scientific, Waltham, US) program was employed with initial denaturation at $95^{\circ} \mathrm{C}$ for $3 \mathrm{~min}$, followed by 35 cycles of $95^{\circ} \mathrm{C}$ for $1 \mathrm{~min}, 52^{\circ} \mathrm{C}$ for $30 \mathrm{~s}, 72^{\circ} \mathrm{C}$ for $1 \mathrm{~min}$ and final extension at $72^{\circ} \mathrm{C}$ for $10 \mathrm{~min}$. The amplicons were purified on Clean-Up columns (A\&A Biotechnology) and used for library construction. Sequencing was carried out with a MiSeq Reagent Kit v2 (2x250 bp) using a MiSeq (Illumina) platform. Details concerning the preparation of libraries were presented in our previous study (Szczepaniak et al., 2016). After sequencing, the raw data in FASTQ format were imported to the CLC Genomics Workbench 8.5 software with the CLC Microbial Genomics Module 1.2 (CLCbio, Qiagen Bioinformatics, Aarhus, Denmark). The reads were demultiplexed, and paired ends were merged (mismatch cost $=2$, $\min$ score $=8$, Gap cost $=3$, max unaligned end mismatches $=5$ ). Primer sequences were trimmed (quality limit $=0.05$, ambiguous limit $=$ 'N'), and the identification and elimination of chimeric reads was performed. The output data were clustered independently based on two reference databases, namely SILVA v119 (Quast et al., 2013) and GreenGenes 13.5 (DeSantis et al., 2006) at a 97\% probability level of OTUs (operational taxonomic units). The alpha-biodiversity (number of OTUs) factor was determined based on the merged abundance table (clustered against SILVA v119). The final sequencing datasets generated and analyzed within the framework of this study are available in the SRA repository, with the identifier SRP156685 (https://www.ncbi.nlm.nih.gov/sra/SRP156685).

Overall, we selected three microcosms supplemented with D, B20 and B100 non-augmented and augmented treatments (D+, B20+, B100+). B20 has received significant attention and is 
one of the most commonly investigated biodiesel blend (Cyplik et al., 2011; Demirbas, 2007; Junior et al., 2009; Meyer et al., 2012; Silva et al., 2012). According to our study, mineralization extent in $\mathrm{B} 20$ blend microcosms presented the most unexpected pattern and therefore this microcosm was selected for further genetic analysis.

It should be noted that the results of the Illumina MiSeq sequencing may be limited by the lack of replicates of sequencing data. This prevented the possibility to employ a multivariate statistical analysis and evaluate the statistical significance of the observed differences. In consequence, it was not possible to assess the trends of microbial community shifts at a statistical level. The highlighted issue may be of particular importance in case of complex terrestrial matrices, in case of which the isolation of DNA is challenging. In the framework of this study the data obtained based on Illumina MiSeq sequencing was primarily used to evaluate the efficiency of the bioaugmentation process. Additionally, an attempt to elucidate the "key players" which participate in the biodegradation of various diesel/biodiesel blends.

\subsection{Mineralization kinetics and statistical analysis}

As the experiment proceeded, it was observed that the curves expressing the increase of cumulative $\mathrm{CO}_{2}$ evolution were neither linear nor logarithmic. Hence, for a matter of simplicity, two sections (namely from day 0 until day 28 , as a beginning of the experiment, and from day 33 to day 109, as the most intensive period), where mineralization curves were approximately linear $\left(\mathrm{R}^{2} \geq 0.95\right)$, were selected for further analysis. Subsequently, zero-order kinetics model was applied to describe and compare the kinetics of organic matter mineralization (associated mainly with the fuels additions), between the investigated experimental setups. Similar approaches to characterizing mineralization kinetics in porous media were presented previously (Dechesne et al., 2010; Owsianiak et al., 2010). The oneway ANOVA with $\mathrm{p}<0.05$ were used for statistical comparisons. This approach was also 
employed for statistical analysis of metagenomic data in order to establish the significance of differences for untreated vs non-bioaugmented and non-bioaugmented vs bioaugmented systems.

\section{Results}

\subsection{Evolution of $\mathrm{CO}_{2}$ and mineralization kinetics}

Mineralization extent of the different fuel blends was measured as amount of $\mathrm{CO}_{2}$ released in the microcosms (corrected for the background, substrate-unamended control), as summarized in Table 1 and Fig. 1. In non-augmented microcosms, mineralization extent increased with increasing biodiesel content, and ranged from $44.1 \pm 2.3$ for $\mathrm{B} 10$ to $48.8 \pm 2.4 \mathrm{mmol} \mathrm{CO}_{2}$ for B100 (Table 1). For diesel, mineralization extent was the highest and equal to $49.9 \pm 3.8$ mmol. The evolution of $\mathrm{CO}_{2}$ in all samples differed significantly from that in the controls $(9.7$ $\pm 1.1 \mathrm{mmol}$ ) without any fuel addition (Fig. 1). In bioaugmented microcosms, the mineralization extent did not increase with increasing biodiesel content as in non-augmented samples. The highest $\mathrm{CO}_{2}$ evolution were observed for $\mathrm{B} 20(48.5 \pm 3.1 \mathrm{mmol})$, while the lowest for B50 (42.9 $\pm 2.1 \mathrm{mmol})$. However, there were no statistically significant differences between the mineralization extent of non-augmented and augmented diesel/biodiesel blends, apart from pure diesel microcosms $(\mathrm{p}=0.047)$.

Regression performed on non-augmented and augmented mineralization curves presented the influence of biodiesel content on mineralization extent during short- (days 0-28) and longterm (days 33-109) mineralization phases (Table 1). Linear regressions applied on the mineralization curves for non-augmented samples revealed that mineralization rate constants were higher for higher biodiesel blends. This was generally true for both mineralization phases. However, it is worth noticing that the mineralization rate constants of non-augmented B10-B30 microcosms were lower than of microcosms spiked with pure diesel (D) in both 
phases. On the other hand, regressions for augmented samples showed that mineralization rate constants were higher in the short-term mineralization phase compared with non-augmented samples (apart from D+, B80+ and B100+). In the long-term phase, however, the opposite was observed. There were statistically significant differences in rate constants during shortterm mineralization phase of non-augmented and augmented samples for lower biodiesel blends from B10 to B60 ( $\mathrm{p}<0.05)$, while in long-term phases the significant differences were observed only for B40 $(\mathrm{p}=0.046)$ and B50 $(\mathrm{p}=0.041)$.

\subsection{Fate of hydrocarbons and FAME}

Based on GC-FID and GC×GC-TOF-MS studies after 64.5 weeks, biodiesel was completely degraded in all diesel/biodiesel blends (Fig. S1. Supporting Information). Depending on the blends, the total petroleum hydrocarbon residues ranged from 3 to $12 \%$ of the introduced hydrocarbon fractions in samples without bioaugmentation, and from 4 to $8 \%$ in samples with bacterial augmentation. After 64.5 weeks, there were no statistical differences between blends in case of total hydrocarbon residues $(\mathrm{p}>0.05)$ in non-augmented and augmented treatments. No clear effect of the type of blend on ratio of remaining to initial masses of hydrocarbon fractions (aliphatic and aromatic factions) was observed, apart from B80-B90 blends where the increase in this ratio were determined. Moreover, the ratio of residual aromatic to aliphatic fraction at the end of the experiment remained unchanged for all treatments (Fig. S2. Supporting Information).

\subsection{Bacterial community structure in non-augmented and augmented soil}

Figure 2A shows the contribution of ten most abundant bacterial phyla in bacterial community (BC125), untreated soil sample (control) and microcosms supplemented with different fuels without (B100, B20, D) and with (B100+, B20+, D+) bioaugmentation treatment. 
The most dominant microbial phyla detected in untreated urban soil (Fig. 2A control) were Proteobacteria (45.64\%), followed by Planctomycetes (15.41\%), Clostridia (10.11\%), Chloroflexi (12.63\%), Acidobacteria (8.78\%) and Actinobacteria (5.54\%). The rest of the identified microbial taxa were estimated below $5 \%$ of total detected taxonomic ranks $(\mathrm{p}=$ 0.011). The microbial community structure changed between the treatments (i.e. controls vs treatments with B100, B20 and D soil samples) after 64.5 weeks exposure. The relative abundance of Bacteroidetes increased in case of samples spiked with B100, B20 and D by 5, 12 and 6\% respectively. The increase in abundance of Actinobacteria was also observed for soils supplemented with fuels (B100 by $8 \%$, B20 by $2 \%$ and D by $3 \%$ ). On the other hand the contribution of Planctomycetes deceased in each B100, B20 and D spiked soils by 7, 5 and 3\%, respectively, while the contribution of both Chloroflexi and Acidobacteria deceased by 1$3 \%$ depending on the fuel. No changes were determined for Proteobacteria, the most abundant phylum $(\mathrm{p}=0.123)$. The supplementation of urban soil with different fuel and oildegrading bacteria (B100+, B20+, D+) did not affect significantly the composition of their bacterial community structure compared with non-augmented samples (B100, B20, D) (p = 0.094). However, the relative abundance of Proteobacteria increased by 7 and $8 \%$ for B20+ and D+ with reference to samples without bioaugmentation treatments. The highest increase (by $15 \%$ ) was observed for Bacteroidetes in soil supplemented with pure diesel (D+), even though the abundance of Bacteroidetes decreased by $5 \%$ in B20+ samples. The contribution of Planctomycetes increased by $2 \%$ for $\mathrm{B} 100+$, while for $\mathrm{B} 20+$ and $\mathrm{D}+$ the contribution decreased by 2 and $6 \%$, respectively. The abundance of Actinobacteria and Chloroflexi deceased with the increased amount of diesel fuel (even by 7\% depending on phylum).

Figure 2B shows the ten most abundant bacterial classes in non-augmented (B100, B20, D) and augmented (B100+, B20+, D+) soil spiked with appropriate fuels. The most dominant microbial classes detected in the untreated soil (control) were Alphaproteobacteria $(19.41 \%)$, 
Gammaproteobacteria (15.45\%), Planctomycetacia (14.91\%), Acidobacteria (7.69\%) and Betaproteobacteria (6.84\%). All other classes that were identified represented $<5 \%$ of total identified taxonomic ranks $(\mathrm{p}=0.018$ ). These results revealed that both Sphingobacteriia and Actinobacteria increased their relative abundance in all samples supplemented with B100, B20 and D by $5,12,6 \%$ and $11,2,4 \%$, respectively. Notably, the contribution of both classes did not exceed $1 \%$ in untreated soil sample $(\mathrm{p}=0.016)$. The increase of the abundance of Sphingobacteria was caused by the increased ratio of bacteria belonging to the Chitinophagaceae genus in this class. This genus was predominant and its ratio exceeded $95 \%$ in this class. In turn, the increased ratio of bacteria belonging to the Actinobacteria class was caused by the increased abundance of the following genera: Arthrobacter, the increase of which was particularly high in case of addition of biodiesel, and Corynebacteriales. A decrease of bacteria belonging to the Gaiellales genus was also observed in this class, for which the contaminants introduced into soil were toxic. The ratio of this genus in the Actinobacteria class decreased from $52 \%$ (control soil) to $2-7 \%$ in contaminated soil samples. The relative abundance of Gammaproteobacteria increased by $2 \%$ for B100, while that in the B20 and D treatments decreased by 2 and 9\%, respectively. The following bacterial genera were predominant in the Gammaproteobacteria class: Aquicella (46\%), Arenimonas (15\%), Lysobacter (15\%) and Thermomonas (7.4\%). The ratio of Aquicella and Thermomonas did not change in case of soils supplemented with diesel, however the abundance of Arenimonas and Lysobacter decreased significantly to 2.7 and $2.4 \%$, respectively. In case of samples supplemented with biodiesel (B20 and B100) a notable decrease of all the above-mentioned genera was observed. Changes were also noted in case of the Pseudomonas genus, the ratio of which in control soil amounted to $0.35 \%$. The addition of B100 caused a significant increase to $40 \%$, which decreased in case of B20 (27\%) and diesel (2.7\%). A significant increase (by $7 \%$ ) of the Betaproteobacteria for samples spiked with pure diesel was detected. In case of 
the Betaproteobacteria class, the following genera were predominant in control soil: Acidovorax (47\%), Noviherbaspirillum (21\%) and Ralstonia (2.8\%). In the sample supplemented with diesel (D), the abundance of Acidovorax did not change, whereas the ratio of Noviherbaspirillum and Ralstonia increased to 30 and $7.6 \%$, respectively. On the other hand, the decrease in abundance of Planctomycetacia (by 7\% for B100, 5\% for B20, and 3\% for D) and Acidobacteria (by 3\% for B100, 3\% for B20, and 2\% for D) was also observed. No significant changes were estimated in the most abundant class, Alphaproteobacteria $(\mathrm{p}=$ $0.131)$.

Within bacterial classes, the differences between non-augmented and augmented samples were more visible, however still bioaugmentation treatment did not affect significantly the community structures $(\mathrm{p}=0.097)$. Similar to non-augmented soil, the increase in abundance of Sphingobacteriia (by 9\% for B100+, 9\% B20+ and 14\% D+) and Actinobacteria (by 6\% for $\mathrm{B} 100+, \mathrm{B} 20+, \mathrm{D}+)$ were determined with reference to untreated soil (control). The increased ratio of bacteria belonging to the Sphingobacteriia class resulted from the increased abundance of uncultured bacteria belonging to the Chitinophagaceae family. These bacteria were part of the autochthonous population and were not present in BC125. In control soil, this genus comprised $50 \%$ of bacteria belonging to Sphingobacteriia, whereas in case of samples supplemented with diesel (D), B20 and B100 their abundance was equal to 55, 83 and 96\%, respectively. The increased ratio of the Actinobacteria bacterial class was caused by the increase of the following genera: Arthrobacter, which was particularly predominant in case of biodiesel (58\%), and Cellulosimicrobium (18\%). In the framework of this class the decrease of bacteria belonging to the Gaiellales genus was observed, for which the contaminants were toxic. Its ratio in the Actinobacteria class decreased 52\% (control soil) to $5.3 \%$ in samples supplemented with diesel oil. However, compared to soil without bioaugmentation, the highest increase (by 4, 5 and $16 \%$ for B100+, B20+ and D+, respectively) were determined 
for Gammaproteobacteria. It is worth noting that the contribution of Gammaproteobacteria in BC125 reached $13.31 \%$ (see Materials \& Methods section, 2.2. Microorganisms). In contrast to samples without bioaugmentation, the Pseudomonas genus was predominant in the Gammaproteobacteria class. Its ratio in the soil microbiome was equal to $82 \%$ (D+), $62 \%$ (B20) or $29 \%$ (B100). Interestingly, its ratio in BC125 was low (equal to $0.6 \%$ ). The ratio of genera Aquicella, Arenimonas, Lysobacter and Thermomonas, which were predominant in control soil, was notably decreased in samples supplemented with diesel (D+) or biodiesel (B20+ and B100+). The abundance of Alphaproteobacteria decreased by $4 \%$ for B100+, while for B20+ and D+ members of this class increased by 3 and $4 \%$, respectively. Sphingomonas genus was predominant in the Alphaproteobacteria class. In BC125 it comprised $46 \%$ of all bacteria, and up to $92 \%$ of bacteria belonging to the Alphaproteobacteria class. In comparison with control soil (34\% among Alphaproteobacteria) its ratio decreased to $24 \%(\mathrm{~B} 100+), 11 \%$ (B20) or $7.4 \%$ (D), respectively. It should be highlighted that these changes were not significant $(p=0.134)$, considering that Alphaproteobacteria was the most abundant bacterial class in $\mathrm{BC} 125$ (46.85\%). The increased abundance of Acidobacteria for B20+ (by 6\%) was also identified. In case of Acidobacteria, all the changes of resulted from the increased abundance of uncultured bacteria belonging to Subgroup 4 and 6. However, the most visible changes were observed for soil (D+) spiked with pure diesel and BC125, where an increase in Flavobacteriia (by 8\%) and a simultaneous decrease in Planctomycetacia (by 6\%) and Betaproteobacteria (by 9\%) compared with soil (D) without addition of bacterial community were determined. Changes in the Flavobacteriia class were caused by shifts of the abundance of bacteria belonging to the Flavobacterium genus. It can be assumed that this genus was introduced into the soil with the biopreparation, since its ratio in the control soil was below $0.01 \%$. Furthermore, it did not occur in any sample of soil contaminated with hydrocarbons. It 
is difficult to explain its high ratio. The decrease of Planctomycetacia in D+ soil relative to D soil was caused by the decreased ratio of the Planctomycetaceae family, particularly of uncultured genera belonging to this family. In case of Betaproteobacteria, The decreased ratio in D+ soil relative to D soil was associated with the decrease abundance of Acidovorax and Noviherbaspirillum families. No significant changes $(\mathrm{p}=0.119)$ were observed for Bacilli, which was second most abundant class $(22.71 \%)$ in $\mathrm{BC} 125$.

After 64.5 weeks, the alpha diversity estimates were also determined for untreated soil, BC125, autochthonic microcosms (B100, B20, D) and bioaugmented autochthonic microcosms (B100+, B20+, D+). The mean value of the observed OTU's for the untreated soil samples was equal to 2,268. The microcosms supplemented with B100 and B20 caused significant increase $(\mathrm{p}<0.05)$ in the values of OTUs and reached 2,592 and 2,314; respectively. The enhancement was also established for the same microcosms supplemented with bacterial community, however no considerable differences between augmented and nonaugmented samples were observed $(\mathrm{B} 100+=2,516$; B20 $+=2,363)$. For diesel treated soil with and without bacterial inoculation the mean values of observed OTUs were the lowest and did not differ significantly $(p>0.05)$ in comparison to untreated soil $(\mathrm{D}=2,214 ; \mathrm{D}+=2,219)$.

\section{Discussion}

\subsection{Long-term mineralization of diesel/biodiesel blends in urban soil}

Lisiecki et al. (2014) demonstrated that in porous matrices (sterile sand) the increase of biodiesel content in blends was positively correlated with an increase in their mineralization extent after 82.5 weeks. Here, the results showed that after long-term exposure the mineralization extents in urban soil with autochthonous microorganisms were similar and clearly not dependent on the amount of biodiesel in fuels. Many authors emphasized the tremendous adaptation capacity of autochthonous microorganism to harsh conditions 
(Bouchez et al., 2000; Vogel, 1996), especially when the time is sufficient enough to fully adapt and consequently degrade exogenously added xenobiotics. According to Thompson et al. (2005), indigenous microorganisms are the most suitable candidates for slow and continuous degradation of pollutants during long-term exposure. Prior studies have also noted that the former oil contaminated soils are often the most promising source for isolation of efficient hydrocarbon-degrading bacteria (Owsianiak et al., 2009b; Rahman et al., 2002; Szczepaniak et al., 2016). Hence, in the soil from city park placed next to the main road, the presence of hydrocarbon-degrading community among autochthonous microorganisms was expected. Based on Illumina MiSeq sequencing more than one third of microbial classes abundance detected in the untreated soil belonged to Alphaproteobacteria and Gammaproteobacteria. Plethora of studies indicated that both Alphaproteobacteria, Gammaproteobacteria as well as Bacilli and Actionbacteria which were also the most dominant classes in bacterial community (BC125), are in fact well-known hydrocarbon degraders in soil and have been often enriched during biodegration of hydrocarbons (Fuentes et al., 2015; Marchand et al., 2017; Tiralerdpanich et al., 2018).

Although, the mineralization extent after long-term exposure was almost equal for each fuel, we revealed that the increase of biodiesel content in blends caused the enhancement of mineralization extent, especially at short- and long-term mineralization phases. The presence of FAMEs has been already reported to accelerate the biodegradation of diesel in experiments (up to 28 and 60 days) in different types of porous matrixes, such as sand soil (Horel and Schiewer, 2011), oxisol (Meyer et al., 2014) or soil from rain forest (Silva et al., 2012). Several studies emphasized that biodegradation of both FAMEs and $n$-alkanes undergo similar metabolism via $\beta$-oxidation mechanism (Lisiecki et al., 2014; Sydow et al., 2016; Yassine et al., 2013), thus the acceleration in mineralization in the presence of biodiesel might be expected. Our findings are consistent with Yassine et al. (2013), who suggested that this 
was a result of co-solubilization mechanisms rather than cometabolism, for which the latter occurs mainly when one of the substrates is not readily biodegradable. The authors clearly determined that the ability of FAMEs to co-solubilize the $n$-alkanes is associated with reduction of interfacial surface tension and enhancement of their bioavailability for microorganisms. However, DeMello et al. (2007) presented that the acceleration of $n$-alkanes degradation in the presence of FAMEs in seawater microcosms took place only in early stage of the experiment. After longer time (53 days), the authors determined no effect of biodiesel on composition of the residual mixtures. They emphasized that the long period of time caused this lack of differences in terms of hydrocarbon composition between diesel and its biodiesel blends, which might be also explain our results. Mariano et al. (2008) also showed that in experiments lasting up to 120 days, no stimulation effect of FAMEs (B2, B5, B20) on diesel degradation in both soil from a petrol station and water samples were found. Taken collectively, it can be concluded that in short-term exposure, FAMEs is expected to increase the mineralization extents of different kinds of diesel/biodiesel blends, whereas in the longterm FAMEs had no visible influence on their mineralization extent.

Our study also revealed that the mineralization rate constants of B10-B30 blends in urban soil were lower than of diesel fuel (D) during short- and long-term exposure, while generally for higher diesel/biodiesel blends (above B30) the higher mineralization rates were determined. This is in accordance with Owsianiak et al. (2009a), who noticed that only the introduction into petroleum diesel above $30 \%$ of biodiesel contribute to the enhancement of biodegradation efficiency in aqueous media. No positive effect of low content of biodiesel (even up to B20) on diesel degradation were also observed in other study (Mariano et al., 2008). Thus, it might be concluded that the positive effect on the biodegration efficiency of diesel/biodiesel blends in soil microcosms can be expected only after exceeding a certain concentrations of biodiesel added to conventional fuel. 
No correlation between introduced and residual amount of hydrocarbons were determined after long-term exposure, which might suggest that biodiesel addition had neither stimulating nor inhibiting effect on hydrocarbon biodegradation. However, it is highly probable that in short-term period this observation would be different. According to Yassine et al. (2013), FAMEs enhanced the mineralization rates of both aliphatic $\left(\mathrm{C}_{10}-\mathrm{C}_{21}\right)$ and aromatic (toluene, $o$-xylene, tetraline) hydrocarbons in acclimated activated sludge within 7 days. Such observation was explained by better solubilization of hydrocarbons in the presence of FAMEs. But it was also shown that biodiesel was a better growth substrate than diesel (Bücker et al., 2011; Owsianiak et al., 2009a), and thus FAMEs were able to increase the degradation rates of $n$-alkanes by enhancing beforehand the biomass growth (Yassine et al., 2013).

The microbial community analysis revealed that after 64.5 weeks exposure to different diesel/biodiesel blends, the bacterial profiles changed in comparison to untreated soil. The observation provided by Szczepaniak et al. (2016) indicated no significant differences in soil microbiome after 3 months of PAHs degradation in relation to uncontaminated soil. Although in our study the bacterial community structure returned partially to their initial composition, the significant increase in contribution of Actinobacteria and Sphingobacteriia were determined. Both classes are well-known hydrocarbon degraders (Isaac et al., 2015; Janbandhu and Fulekar, 2011; Lisiecki et al., 2014). Actinobacteria is widely described to be able to degrade aliphatic and aromatic hydrocarbons in both aquatic and soil environments (De Pasquale et al., 2012; Isaac et al., 2015), while Sydow et al. (2016) clearly showed that Sphingobacterium spp. can be $n$-alkane-degrading specialists. Previous studies have reported that fatty acids from FAMEs revealed structural and metabolic similarities with $n$-alkanes and their metabolites of biological oxidation (alcohols, aldehydes and acids) (Fulco, 1983; Lisiecki et al., 2014; Wentzel et al., 2007; Yassine et al., 2013). Thus, it was expected that $n$ - 
alkane-degraders able also to successfully degrade FAMEs will appear. Moreover, Lisiecki et al. (2014) determined that there was neither inhibiting nor stimulating effect of different FAMEs content on Sphingobacterium during degradation of broad range of diesel/biodiesel blends in sand microcosms. On the other hand, several studies demonstrated that the increased growth of Gammaproteobacteria was stimulated by the presence of biodiesel (Cyplik et al., 2011; Lisiecki et al., 2014; Sydow et al., 2016). Although we did not observe an increased abundance in the Gammaproteobacteria in the presence of pure biodiesel, the significant decrease for members of this class was observed with a decreased FAMEs content in urban soil. Furthermore, our results are also in agreement with those reported by Cyplik et al. (2011), who presented the suppression effect of biodiesel on the abundance of Betaproteobacteria. Here Betaproteobacteria increased two-fold to its contribution when urban soil was spiked with pure diesel. Lors et al. (2012) found that in soil polluted by coal tar, Betaproteobacteria appeared in bacterial community after three months when concentrations of PAHs were non-toxic and low enough to maintain such conditions. They suggested that Betaproteobacteria taxa could act as a bio-indicator for the endpoint of the bioremediation processes. Therefore, more work is needed to determine the influence of diesel/biodiesel blends on bacterial community in field conditions as limitation in carbon source and nutrients availability may play a critical role in community structure changes.

\subsection{Influence of bioaugmentation approach on diesel/biodiesel blends}

The concept of inoculating the hydrocarbon-polluted areas with fast-degrading microorganisms in order to increase the biodegradation rate and reduce the time to enhance the bioremediation efficiency has been developed for many years (Gentry et al., 2004; Mukherjee and Bordoloi, 2011; Szulc et al., 2014). In previous studies, single strains, mixed cultures or consortia were used as inocula (Cerqueira et al., 2011; Junior et al., 2009; Rahman 
et al., 2002). Tyagi et al. (2011) suggested that strategies involving the use of microbial consortia, rather than a single culture, is more beneficial for bioremediation as it provides biodiversity and robustness, as is depictive for the real environment. Following this assumption we used a hydrocarbon-degrading bacterial community isolated from oilcontaminated soil, as we determined a high biodegradation potential.

The biodegradation kinetics presented the intensive activity only within first 28 days (shortterm phase), while during long-term phase (33-109 days) no enhancement in mineralization rates compared with non-augmented microcosms were determined. This finding suggested that the microbial community had a positive effect on biodegradation of diesel/biodiesel blends only after inoculation, while over time the efficiency of bioaugmentation had decreased. Our results are in accordance with Szczepaniak et al. (2016), who determined that the bioaugmentation of soil contaminated with PAHs was successful only during the early stage of treatment, while after a few months the bacterial community composition returned to the previous conditions. In the present study, after 64.5 weeks the bacterial profile of diesel/biodiesel-contaminated soil, when augmented with bacterial community, was found to be comparable to non-augmented samples. One possible explanation is that the microbial community did not adapt sufficiently to survive this long-term exposure. Goldstein et al. (1985) described that possible failure of bioaugmentation might be justified by low growth rates of supplemented microorganisms in relation to indigenous microorganisms, when in soil microcosms various easy available carbon sources were presented. Prior studies emphasized also the significant importance of interaction between inoculated and autochthonous microorganisms in terms of their viability, activity and proliferation (El Fantroussi and Agathos, 2005; Goldstein et al., 1985; Thompson et al., 2005), indicating that supplementation of contaminated site with autochthonous microorganisms is more beneficial in long-term degradation of pollutants. Within this work, the applied bacterial community was 
non-indigenous microorganisms, isolated from different environmental conditions. Hence, this might be the reason why the bioaugmentation was diminished after some time. However, the procedure using non-autochthons fast degraders has been already successfully applied in previous studies (Junior et al., 2009; Stella et al., 2017; Teng et al., 2010).

On the other hand, Johnsen et al. (2007) determined that priming the PAH-polluted soil by adding as inoculum bioremediated soil with a high hydrocarbon degradation potential resulted in the increase even up to 1,000 times the number of cultivable PAH-degraders. This means that the soil-adapted community has demonstrated the high survival rate, persistence and proliferation in PAH-contaminated soil during the experiment lasting 16 weeks. Although, the introduction to hydrocarbon polluted microcosms soil-adapted degraders seems to be beneficial, such treatment had no significant effect on hydrocarbon degradation, which accords with our observations. The higher degradation rates of phenanthrene, fluoranthen and pyrene were determined only within few weeks after inoculation, in the end the degradation rates of primed and not primed microcosms were comparable. Recent studies have described the significant impact of soil matrices on biodegradation success (Bento et al., 2005; Horemans et al., 2016). This issue was described by Horemans et al. (2016), who determined the biodegradation potential of phenanthrene-degrading bacterial on twenty uncontaminated, sterile soils with various physico-chemical characteristics. The authors revealed that there were differences in the extent of phenanthrene degradation, and that this was dependent on the soil properties. Although, to simplify the models, they did not consider the influence of biotic factors, which might strongly affect activity and survival of supplemented microorganisms; they hence developed a three-step tool for predicting the bioaugmentation success. Based on models described in their study, the soil used within the framework of this research was classified as soil with potential to survival with medium degrading activity of bioaugmented strain. However, in terms of our soil, the authors recommended the bioaugmentation together 
with biostimulation as a good and effective biodegradation strategy. Therefore, the effectiveness of bioaugmentation approach of diesel/biodiesel contaminated site depend on both selection of appropriate microorganisms treatment and compatible soil to successfully enhance the chances of bioaugmentation in urban microcosms.

\section{Conclusions and practical implications}

The present study demonstrated that after long-term exposure (64.5 weeks), the mineralization extent of different diesel/biodiesel blends in urban soil does not depend on biodiesel concentration in fuel. This finding suggests that giving sufficient time for biodegradation of such blends from soil might be an effective bioremediation strategy. However, the addition of biodiesel to conventional diesel fuel increases the biodegradation kinetics. Thus, during short periods of time diesel/biodiesel blending higher than $30 \%$ seems to be beneficial for bioremediation of petroleum mixtures spills. This study has shown that bioaugmentation can potentially be effective only during the early stages of treatment, whereas after long-term exposure no differences in mineralization extent and bacterial community structure between augmented and non-augmented microcosms occur. It would therefore seem that a beneficial approach in our long-term treatment would be to use successive bioaugmentation. Corroborating this, Colla et al. (2014) suggested that successive bioaugmentation was an effective strategy in bioremediation of soil polluted with diesel/biodiesel blends. Several studies (Łebkowska et al., 2011; Tahhan et al., 2011) demonstrated that multiple inoculation of hydrocarbon-contaminated soil with autochthonous and non-autochthonous microorganisms revealed satisfactory results, and such approaches could be applied as a powerful tool in bioremediation. Moreover, according to Tahhan et al. (2011), additional supplementation of bacterial consortium into soil during petroleum hydrocarbons degradation significantly improved the removal of aromatic and asphaltic fractions, whose biodegradation 
is usually much slower. Collectively, our findings suggest that single bioaugmentation treatment might not be enough to significantly accelerate the removal of hydrocarbon contaminations from urban soil matrix. Therefore, in order to enhance biodegradation, when time is not a limiting factor, the use of bioaugmentation approach may not be an adequate and justifiable solution.

\section{Acknowledgment}

The research work was funded by the National Science Centre in Poland in the years 20142018 with the research project Opus no 2013/11/B/NZ9/01908.

Supporting Information. Fig. S1 - Effect of the amount of biodiesel in blends on the residual of total diesel/biodiesel blends and hydrocarbons fractions; Fig. S2 - Ratio of saturated to unsaturated fraction of diesel residues.

\section{References}

Atashgahi, S., Sánchez-Andrea, I., Heipieper, H.J., Van Der Meer, J.R., Stams, A.J.M., Smidt, H., 2018. Prospects for harnessing biocide resistance for bioremediation and detoxification. Science, 360(6390), 743-746. https://doi.org/10.1126/science.aar3778

Bento, F.M., Camargo, F.A.O., Okeke, B.C., Frankenberger, W.T., 2005. Comparative bioremediation of soils contaminated with diesel oil by natural attenuation, biostimulation and bioaugmentation. Bioresour. Technol. 96, 1049-1055. https://doi.org/10.1016/j.biortech.2004.09.008

Bouchez, T., Patureau, D., Dabert, P., Juretschko, S., Doré, J., Delgenès, P., Moletta, R., Wagner, M., 2000. Ecological study of a bioaugmentation failure. Environ. Microbiol. 2, 179-190. https://doi.org/10.1046/j.1462-2920.2000.00091.x 
Bücker, F., Santestevan, N.A., Roesch, L.F., Seminotti Jacques, R.J., Peralba, M. do C.R., Camargo, F.A. de O., Bento, F.M., 2011. Impact of biodiesel on biodeterioration of stored Brazilian diesel oil. Int. Biodeterior. Biodegrad. 65, 172-178. https://doi.org/10.1016/j.ibiod.2010.09.008

Caporaso, J.G., Lauber, C.L., Walters, W. a, Berg-Lyons, D., Huntley, J., Fierer, N., Owens, S.M., Betley, J., Fraser, L., Bauer, M., Gormley, N., Gilbert, J. a, Smith, G., Knight, R., 2012. Ultra-high-throughput microbial community analysis on the Illumina HiSeq and MiSeq platforms. ISME J. 6, 1621-1624. https://doi.org/10.1038/ismej.2012.8

Cerqueira, V.S., Hollenbach, E.B., Maboni, F., Vainstein, M.H., Camargo, F.A.O., Peralba, M. do C.R., Bento, F.M., 2011. Biodegradation potential of oily sludge by pure and mixed bacterial cultures. Bioresour. Technol. 102, 11003-11010. https://doi.org/10.1016/j.biortech.2011.09.074

Colla, T.S., Andreazza, R., Bücker, F., de Souza, M.M., Tramontini, L., Prado, G.R., Frazzon, A.P.G., Camargo, F.A. de O., Bento, F.M., 2014. Bioremediation assessment of dieselbiodiesel-contaminated soil using an alternative bioaugmentation strategy. Environ. Sci. Pollut. Res. 21, 2592-2602. https://doi.org/10.1007/s11356-013-2139-2

Cyplik, P., Schmidt, M., Szulc, A., Marecik, R., Lisiecki, P., Heipieper, H.J., Owsianiak, M., Vainshtein, M., Chrzanowski, Ł., 2011. Relative quantitative PCR to assess bacterial community dynamics during biodegradation of diesel and biodiesel fuels under various aeration conditions. Bioresour. Technol. 102, 4347-4352. https://doi.org/10.1016/j.biortech.2010.12.068

De Pasquale, C., Palazzolo, E., Piccolo, L. Lo, Quatrini, P., 2012. Degradation of long-chain n-alkanes in soil microcosms by two Actinobacteria. J. Environ. Sci. Heal. Part A 47, 374-381. https://doi.org/10.1080/10934529.2012.645786

Dechesne, A., Owsianiak, M., Bazire, A., Grundmann, G.L., Binning, P.J., Smets, B.F., 2010. 
Biodegradation in a partially saturated sand matrix: compounding effects of water content bacterial spatial distribution, and motility. Environ. Sci. Technol. 44, 2386-2392. https://doi.org/10.1021/es902760y

DeMello, J.A., Carmichael, C.A., Peacock, E.E., Nelson, R.K., Samuel Arey, J., Reddy, C.M., 2007. Biodegradation and environmental behavior of biodiesel mixtures in the sea: An initial study. Mar. Pollut. Bull. 54, 894-904. https://doi.org/10.1016/j.marpolbul.2007.02.016

Demirbas, A., 2007. Importance of biodiesel as transportation fuel. Energy Policy 35, 46614670. https://doi.org/10.1016/j.enpol.2007.04.003

Demirbas, A., 2017. The social, economic, and environmental importance of biofuels in the future. Energy Sources, Part B Econ. Planning, Policy 12, 47-55. https://doi.org/10.1080/15567249.2014.966926

DeSantis, T.Z., Hugenholtz, P., Larsen, N., Rojas, M., Brodie, E.L., Keller, K., Huber, T., Dalevi, D., Hu, P., Andersen, G.L., 2006. Greengenes, a chimera-checked 16S rRNA gene database and workbench compatible with ARB. Appl. Environ. Microbiol. 72, 5069-5072. https://doi.org/10.1128/AEM.03006-05

Di Gregorio, S., Siracusa, G., Becarelli, S., Mariotti, L., Gentini, A., Lorenzi, R., 2016. Isolation and characterization of a hydrocarbonoclastic bacterial enrichment from total petroleum hydrocarbon contaminated sediments: potential candidates for bioaugmentation in bio-based processes. Environ. Sci. Pollut. Res. 23, 10587-10594. https://doi.org/10.1007/s11356-015-5944-y

El Fantroussi, S., Agathos, S.N., 2005. Is bioaugmentation a feasible strategy for pollutant removal and site remediation? Curr. Opin. Microbiol. 8, 268-275. https://doi.org/10.1016/j.mib.2005.04.011

Fernández-Álvarez, P., Vila, J., Garrido, J.M., Grifoll, M., Feijoo, G., Lema, J.M., 2007. 
Evaluation of biodiesel as bioremediation agent for the treatment of the shore affected by the heavy oil spill of the Prestige. J. Hazard. Mater. 147, 914-922. https://doi.org/10.1016/j.jhazmat.2007.01.135

Fuentes, S., Barra, B., Gregory Caporaso, J., Seeger, M., 2015. From rare to dominant: A fine-tuned soil bacterial bloom during petroleum hydrocarbon bioremediation. Appl. Environ. Microbiol. 82, 888-896. https://doi.org/10.1128/AEM.02625-15

Fulco, A.J., 1983. Fatty acid metabolism in bacteria. Prog. Lipid Res. 22, 133-160. https://doi.org/10.1016/0163-7827(83)90005-X

Gentry, T., Rensing, C., Pepper, I., 2004. New Approaches for Bioaugmentation as a Remediation Technology. Crit. Rev. Environ. Sci. Technol. 34, 447-494. https://doi.org/10.1080/10643380490452362

Goldstein, R.M., Mallory, L.M., Alexander, M., 1985. Reasons for possible failure of inoculation to enhance biodegradation. Appl. Environ. Microbiol. 50, 977-983.

Horel, A., Schiewer, S., 2011. Influence of constant and fluctuating temperature on biodegradation rates of fish biodiesel blends contaminating Alaskan sand. Chemosphere 83, 652-660. https://doi.org/10.1016/j.chemosphere.2011.02.027

Horemans, B., Breugelmans, P., Saeys, W., Springael, D., 2016. Soil-Bacterium Compatibility Model as a Decision-Making Tool for Soil Bioremediation. Environ. Sci. Technol. acs.est.6b04956. https://doi.org/10.1021/acs.est.6b04956

Isaac, P., Martínez, F.L., Bourguignon, N., Sánchez, L.A., Ferrero, M.A., 2015. Improved PAHs removal performance by a defined bacterial consortium of indigenous Pseudomonas and Actinobacteria from Patagonia, Argentina. Int. Biodeterior. Biodegrad. 101, 23-31. https://doi.org/10.1016/j.ibiod.2015.03.014

Janbandhu, A., Fulekar, M.H., 2011. Biodegradation of phenanthrene using adapted microbial consortium isolated from petrochemical contaminated environment. J. Hazard. Mater. 
187, 333-340. https://doi.org/10.1016/j.jhazmat.2011.01.034

Johnsen, A.R., Schmidt, S., Hybholt, T.K., Henriksen, S., Jacobsen, C.S., Andersen, O., 2007. Strong impact on the polycyclic aromatic hydrocarbon (PAH)-degrading community of a PAH-polluted soil but marginal effect on PAH degradation when priming with bioremediated soil dominated by Mycobacteria. Appl. Environ. Microbiol. 73, 14741480. https://doi.org/10.1128/AEM.02236-06

Junior, J.S., Mariano, A.P., Angelis, D.D.F. De, 2009. Biodegradation of biodiesel / diesel blends by Candida viswanathii. African J. Biotechnol. 8, 2774-2778.

Ławniczak, Syguda, A., Borkowski, A., Cyplik, P., Marcinkowska, K., Wolko, Praczyk, T., Chrzanowski, Pernak, J., 2016. Influence of oligomeric herbicidal ionic liquids with MCPA and Dicamba anions on the community structure of autochthonic bacteria present in agricultural soil. Sci. Total Environ. 563-564, 247-255. https://doi.org/10.1016/j.scitotenv.2016.04.109

Łebkowska, M., Zborowska, E., Karwowska, E., Miaśkiewicz-Peska, E., Muszyński, A., Tabernacka, A., Naumczyk, J., Jeczalik, M., 2011. Bioremediation of soil polluted with fuels by sequential multiple injection of native microorganisms: Field-scale processes in Poland. Ecol. Eng. 37, 1895-1900. https://doi.org/10.1016/j.ecoleng.2011.06.047

Leme, D.M., Grummt, T., Heinze, R., Sehr, A., Renz, S., Reinel, S., de Oliveira, D.P., Ferraz, E.R.A., de Marchi, M.R.R., Machado, M.C., Zocolo, G.J., Marin-Morales, M.A., 2012. An overview of biodiesel soil pollution: Data based on cytotoxicity and genotoxicity assessments. $\quad$ J. Hazard. Mater. 199-200, 343-349. https://doi.org/10.1016/j.jhazmat.2011.11.026

Lisiecki, P., Chrzanowski, Ł., Szulc, A., Ławniczak, Ł., Białas, W., Dziadas, M., Owsianiak, M., Staniewski, J., Cyplik, P., Marecik, R., Jeleń, H., Heipieper, H.J., 2014. Biodegradation of diesel/biodiesel blends in saturated sand microcosms. Fuel 116, 321- 
327. https://doi.org/10.1016/j.fuel.2013.08.009

Lladó, S., Solanas, A.M., de Lapuente, J., Borràs, M., Viñas, M., 2012. A diversified approach to evaluate biostimulation and bioaugmentation strategies for heavy-oilcontaminated soil. Sci. Total Environ. 435-436, 262-269. https://doi.org/10.1016/j.scitotenv.2012.07.032

Lors, C., Damidot, D., Ponge, J.F., Périé, F., 2012. Comparison of a bioremediation process of PAHs in a PAH-contaminated soil at field and laboratory scales. Environ. Pollut. 165, 11-17. https://doi.org/10.1016/j.envpol.2012.02.004

Luque, R., Lovett, J.C., Datta, B., Clancy, J., Campelo, J.M., Romer, A.A., 2010. Biodiesel as feasible petrol fuel replacement: a multidisciplinary overview. Energy Environ. Sci. 3, 1706-1721. https://doi.org/10.1039/c0ee00085j

Marchand, C., St-Arnaud, M., Hogland, W., Bell, T.H., Hijri, M., 2017. Petroleum biodegradation capacity of bacteria and fungi isolated from petroleum-contaminated soil. Int. Biodeterior. Biodegrad. 116, 48-57. https://doi.org/10.1016/j.ibiod.2016.09.030

Mariano, A.P., Tomasella, R.C., Oliveira, L.M. De, Conteiro, J., Angelis, D.D.F. De, 2008. Biodegradability of diesel and biodiesel blends. African J. Biotechnol. 7, 1323-1328.

Meyer, D.D., Beker, S.A., Bücker, F., Peralba, M. do C.R., Guedes Frazzon, A.P., Osti, J.F., Andreazza, R., Camargo, F.A. de O., Bento, F.M., 2014. Bioremediation strategies for diesel and biodiesel in oxisol from southern Brazil. Int. Biodeterior. Biodegrad. 95, 356363. https://doi.org/10.1016/j.ibiod.2014.01.026

Meyer, D.D., Santestevan, N.A., Buecker, F., Salamoni, S.P., Andreazza, R., De Oliveira Camargo, F.A., Bento, F.M., 2012. Capability of a selected bacterial consortium for degrading diesel/biodiesel blends (B20): Enzyme and biosurfactant production. J. Environ. Sci. Heal. Part a-Toxic/Hazardous Subst. Environ. Eng. 47, 1776-1784. https://doi.org/10.1080/10934529.2012.689227 
Miller, N.J., Mudge, S.M., 1997. The effect of biodiesel on the rate of removal and weathering characteristics of crude oil within artificial sand columns. Spill Sci. Technol. Bull. 4, 17-33. https://doi.org/10.1016/S1353-2561(97)00030-3

Mukherjee, A.K., Bordoloi, N.K., 2011. Bioremediation and reclamation of soil contaminated with petroleum oil hydrocarbons by exogenously seeded bacterial consortium: A pilotscale study. Environ. Sci. Pollut. Res. 18, 471-478. https://doi.org/10.1007/s11356-010$0391-2$

Owsianiak, M., Chrzanowski, Ł., Szulc, A., Staniewski, J., Olszanowski, A., OlejnikSchmidt, A.K., Heipieper, H.J., 2009a. Biodegradation of diesel/biodiesel blends by a consortium of hydrocarbon degraders: Effect of the type of blend and the addition of biosurfactants. $\quad$ Bioresour. $\quad$ Technol. $100, \quad 1497-1500$. https://doi.org/10.1016/j.biortech.2008.08.028

Owsianiak, M., Dechesne, A., Binning, P.J., Chambon, J.C., Sørensen, S.R., Smets, B.F., 2010. Evaluation of bioaugmentation with entrapped degrading cells as a soil remediation technology. Environ. Sci. Technol. 44, 7622-7627. https://doi.org/10.1021/es101160u

Owsianiak, M., Szulc, A., Chrzanowski, Cyplik, P., Bogacki, M., Olejnik-Schmidt, A.K., Heipieper, H.J., 2009b. Biodegradation and surfactant-mediated biodegradation of diesel fuel by 218 microbial consortia are not correlated to cell surface hydrophobicity. Appl. Microbiol. Biotechnol. 84, 545-553. https://doi.org/10.1007/s00253-009-2040-6

Quast, C., Pruesse, E., Yilmaz, P., Gerken, J., Schweer, T., Yarza, P., Peplies, J., Glöckner, F.O., 2013. The SILVA ribosomal RNA gene database project: Improved data processing and web-based tools. Nucleic Acids Res. 41, 590-596. https://doi.org/10.1093/nar/gks1219

Rahman, K.S.M., Thahira-Rahman, J., Lakshmanaperumalsamy, P., Banat, I.M., 2002. 
Towards efficient crude oil degradation by a mixed bacterial consortium. Bioresour. Technol. 85, 257-261. https://doi.org/10.1016/S0960-8524(02)00119-0

Saponaro, S., Bonomo, L., Petruzzelli, G., Romele, L., Barbafieri, M., 2001. Polycyclic aromatic hydrocarbons (PAHs) slurry phase bioremediation of a manufacturing gas plant (MGP) site aged soil. Water. Air. Soil Pollut. 135, 219-236.

Schleicher, T., Werkmeister, R., Russ, W., Meyer-Pittroff, R., 2009. Microbiological stability of biodiesel-diesel-mixtures. Bioresour. Technol. 100, 724-730. https://doi.org/10.1016/j.biortech.2008.07.029

Silva, G.S., Marques, E.L.S., Dias, J.C.T., Lobo, I.P., Gross, E., Brendel, M., Da Cruz, R.S., Rezende, R.P., 2012. Biodegradability of soy biodiesel in microcosm experiments using soil from the Atlantic Rain Forest. Appl. Soil Ecol. 55, 27-35. https://doi.org/10.1016/j.apsoil.2012.01.001

Silva, Í.S., Santos, E. d C. d, Menezes, C.R. d, Faria, A.F. d, Franciscon, E., Grossman, M., Durrant, L.R., 2009. Bioremediation of a polyaromatic hydrocarbon contaminated soil by native soil microbiota and bioaugmentation with isolated microbial consortia. Bioresour. Technol. 100, 4669-4675. https://doi.org/10.1016/j.biortech.2009.03.079

Stella, T., Covino, S., Čvančarová, M., Filipová, A., Petruccioli, M., D’Annibale, A., Cajthaml, T., 2017. Bioremediation of long-term PCB-contaminated soil by white-rot fungi. J. Hazard. Mater. 324, 701-710. https://doi.org/10.1016/j.jhazmat.2016.11.044

Sydow, M., Owsianiak, M., Szczepaniak, Z., Framski, G., Smets, B.F., Ławniczak, Ł., Lisiecki, P., Szulc, A., Cyplik, P., Chrzanowski, Ł., 2016. Evaluating robustness of a diesel-degrading bacterial consortium isolated from contaminated soil. N. Biotechnol. 33, 852-859. https://doi.org/10.1016/j.nbt.2016.08.003

Sydow, M., Szczepaniak, Z., Framski, G., Staninska, J., Owsianiak, M., Szulc, A., Piotrowska-Cyplik, A., Zgoła-Grześkowiak, A., Wyrwas, B., Chrzanowski, L., 2015. 
Persistence of selected ammonium- and phosphonium-based ionic liquids in urban park soil microcosms. Int. Biodeterior. Biodegrad. 103, 91-96. https://doi.org/10.1016/j.ibiod.2015.04.019

Szczepaniak, Z., Czarny, J., Staninska-Pieta, J., Lisiecki, P., Zgola-Grzeskowiak, A., Cyplik, P., Chrzanowski, L., Wolko, L., Marecik, R., Juzwa, W., Glazar, K., Piotrowska-Cyplik, A., 2016. Influence of soil contamination with PAH on microbial community dynamics and expression level of genes responsible for biodegradation of PAH and production of rhamnolipids. Environ. Sci. Pollut. Res. 23, 23043-23056. https://doi.org/10.1007/s11356-016-7500-9

Szulc, A., Ambrozewicz, D., Sydow, M., Ławniczak, Ł., Piotrowska-Cyplik, A., Marecik, R., Chrzanowski, Ł., 2014. The influence of bioaugmentation and biosurfactant addition on bioremediation efficiency of diesel-oil contaminated soil: Feasibility during field studies. J. Environ. Manage. 132, 121-128. https://doi.org/10.1016/j.jenvman.2013.11.006

Tahhan, R.A., Ammari, T.G., Goussous, S.J., Al-Shdaifat, H.I., 2011. Enhancing the biodegradation of total petroleum hydrocarbons in oily sludge by a modified bioaugmentation strategy. Int. Biodeterior. Biodegrad. 65, 130-134. https://doi.org/10.1016/j.ibiod.2010.09.007

Taylor, L.T., Jones, D.M., 2001. Bioremediation of coal tar PAH in soils using biodiesel. Chemosphere 44, 1131-1136. https://doi.org/10.1016/S0045-6535(00)00344-1

Teng, Y., Luo, Y., Sun, M., Liu, Z., Li, Z., Christie, P., 2010. Effect of bioaugmentation by Paracoccus sp. strain HPD-2 on the soil microbial community and removal of polycyclic aromatic hydrocarbons from an aged contaminated soil. Bioresour. Technol. 101, 34373443. https://doi.org/10.1016/j.biortech.2009.12.088

Thompson, I.P., Van Der Gast, C.J., Ciric, L., Singer, A.C., 2005. Bioaugmentation for bioremediation: The challenge of strain selection. Environ. Microbiol. 7, 909-915. 
https://doi.org/10.1111/j.1462-2920.2005.00804.x

Tiralerdpanich, P., Sonthiphand, P., Luepromchai, E., Pinyakong, O., Pokethitiyook, P., 2018. Potential microbial consortium involved in the biodegradation of diesel, hexadecane and phenanthrene in mangrove sediment explored by metagenomics analysis. Mar. Pollut. Bull. 133, 595-605. https://doi.org/10.1016/j.marpolbul.2018.06.015

Tyagi, M., da Fonseca, M.M.R., de Carvalho, C.C.C.R., 2011. Bioaugmentation and biostimulation strategies to improve the effectiveness of bioremediation processes. Biodegradation 22, 231-241. https://doi.org/10.1007/s10532-010-9394-4

Vogel, T.M., 1996. Bioaugmentation as a soil bioremediation approach. Curr. Opin. Biotechnol. 7, 311-316. https://doi.org/10.1016/S0958-1669(96)80036-X

Wentzel, A., Ellingsen, T.E., Kotlar, H.K., Zotchev, S.B., Throne-Holst, M., 2007. Bacterial metabolism of long-chain n-alkanes. Appl. Microbiol. Biotechnol. 76, 1209-1221. https://doi.org/10.1007/s00253-007-1119-1

Yassine, M.H., Wu, S., Suidan, M.T., Venosa, A.D., 2013. Aerobic biodegradation kinetics and mineralization of six petrodiesel/soybean-biodiesel blends. Environ. Sci. Technol. 47, 4619-4627. https://doi.org/10.1021/es400360v 


\section{Figure and table captions:}

Fig. 1. Mineralization extent of diesel (D) and diesel/biodiesel blends (B10-B100) in urban soil microcosms without bioaugmentation (1A, 1B - mineralization within first 28 days) and with bioaugmentation (2A, 2B - mineralization within first 28 days). Error bars represents confidence intervals for $\mathrm{p}=0.05$.

Fig. 2. Relative abundance of the most dominant microbial phyla (A) and classes (B) inhabiting soil (control) and soil spike with diesel/biodiesel blends with autochthonic microcosms (B100, B20, D) versus autochthonic microcosms bioaugmented with specialized bacterial community BC125 (B100+, B20+, D+).

Table 1. Mineralization extent and rate constants for different fuels and biodegradation conditions (augmented vs, non-augmented). 
Table 1. Mineralization extent and rate constants for different fuels and biodegradation conditions (augmented vs, non-augmented).

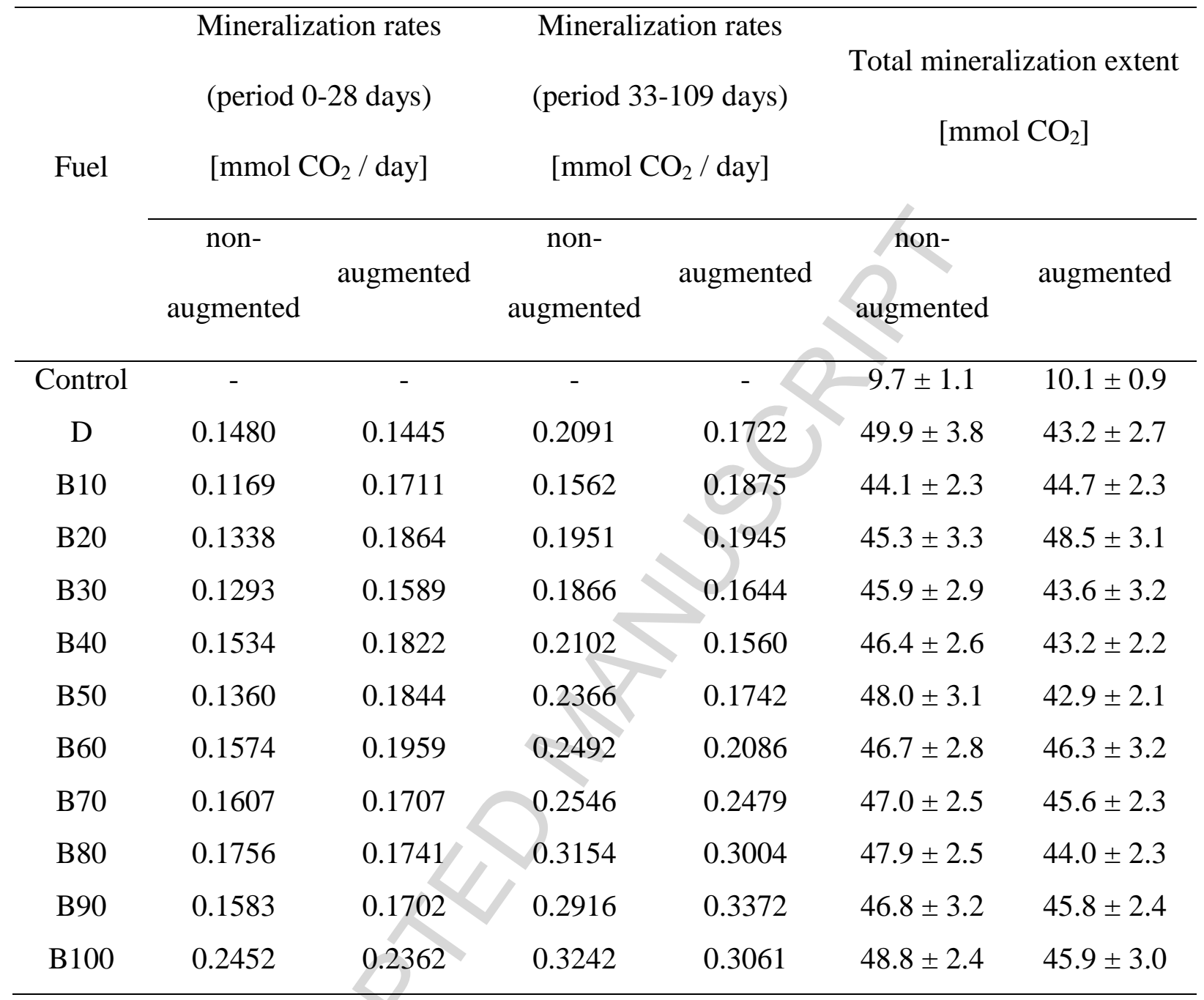

The rates are derived from the slope of the initial (0-28 days) and intermediate (33-109 days) phases of the mineralization curves; $\mathrm{R}^{2}>0.95$ for all samples 


\section{Highlights}

- Long-term (64.5 weeks) biodegradation of diesel/biodiesel in urban soil was studied

- $3-12 \%$ of the total aromatic and aliphatic hydrocarbons remained in the microcosms

- Effect of bioaugmentation was evaluated

- MiSeq sequencing analysis revealed a significant effect of blend type

- No significant influence of bioaugmentation was determined in the long-term 

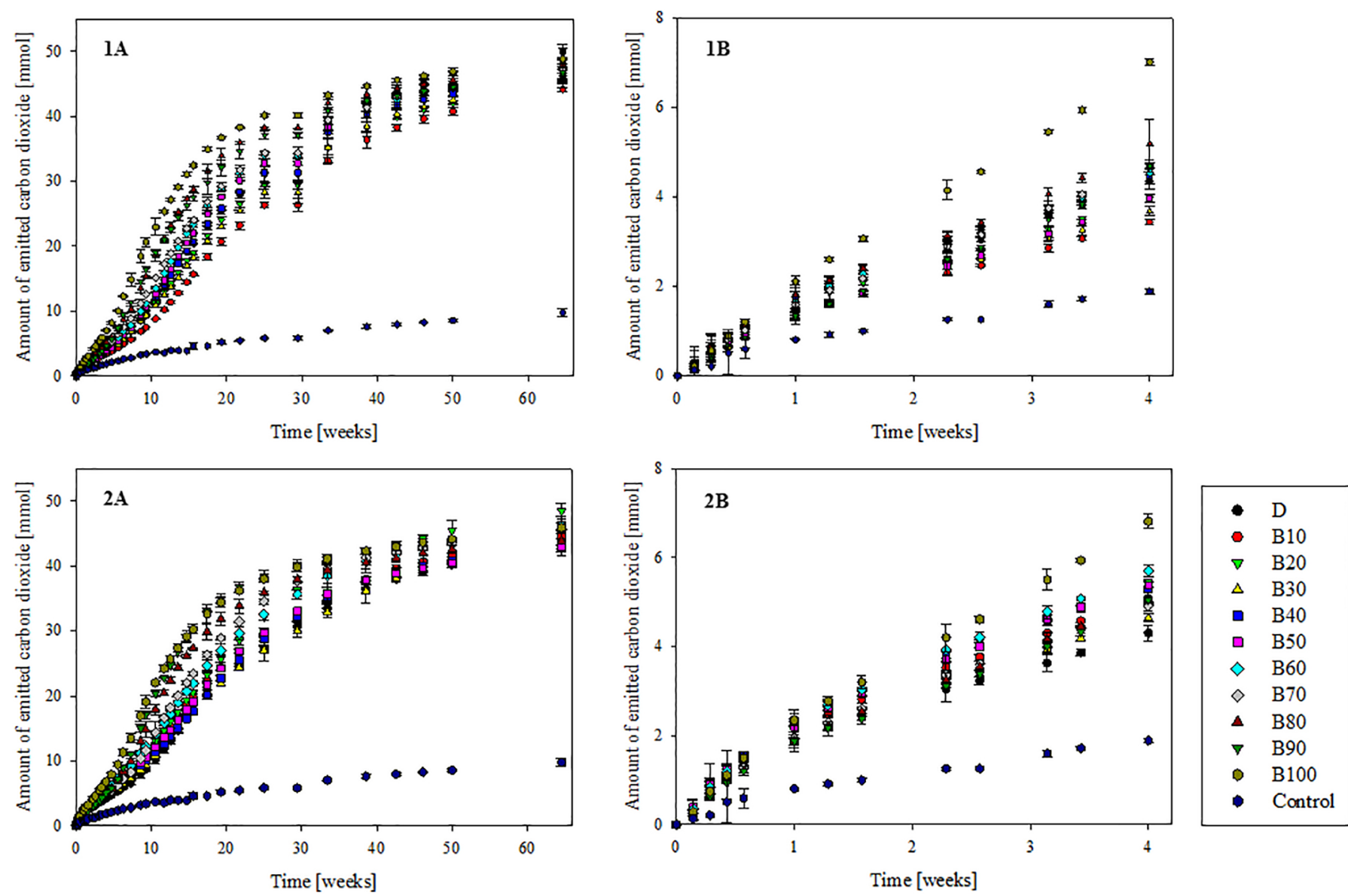

Figure 1 


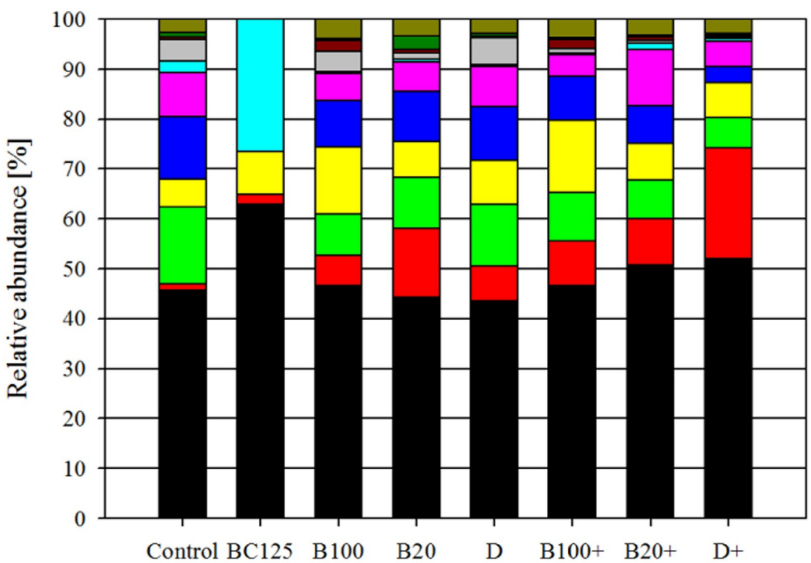

B

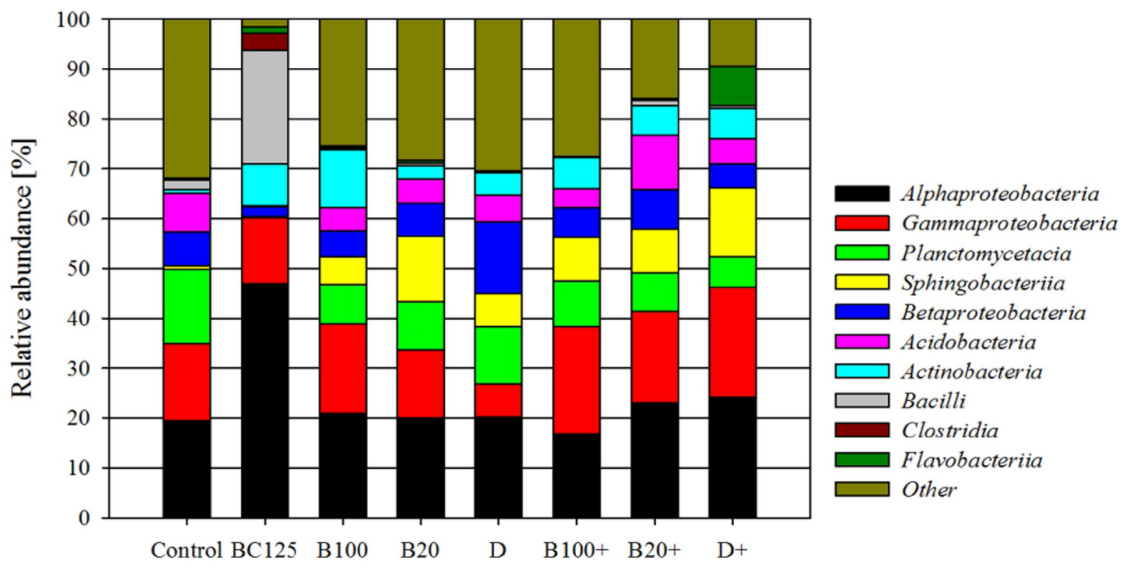

Figure 2 